\title{
Oceanography
}

CITATION

Gordon, A.L. 2012. Circumpolar view of the Southern Ocean from 1962 to 1992.

Oceanography 25(3):18-23, http://dx.doi.org/10.5670/oceanog.2012.69.

DOI

http://dx.doi.org/10.5670/oceanog.2012.69

COPYRIGHT

This article has been published in Oceanography, Volume 25, Number 3, a quarterly journal of The Oceanography Society. Copyright 2012 by The Oceanography Society. All rights reserved.

USAGE

Permission is granted to copy this article for use in teaching and research. Republication, systematic reproduction, or collective redistribution of any portion of this article by photocopy machine, reposting, or other means is permitted only with the approval of The Oceanography Society. Send all correspondence to: info@tos.org or The Oceanography Society, PO Box 1931, Rockville, MD 20849-1931, USA. 


\section{Circumpolar View of the Southern Ocean from 1962 to 1992}

BY ARNOLD L. GORDON

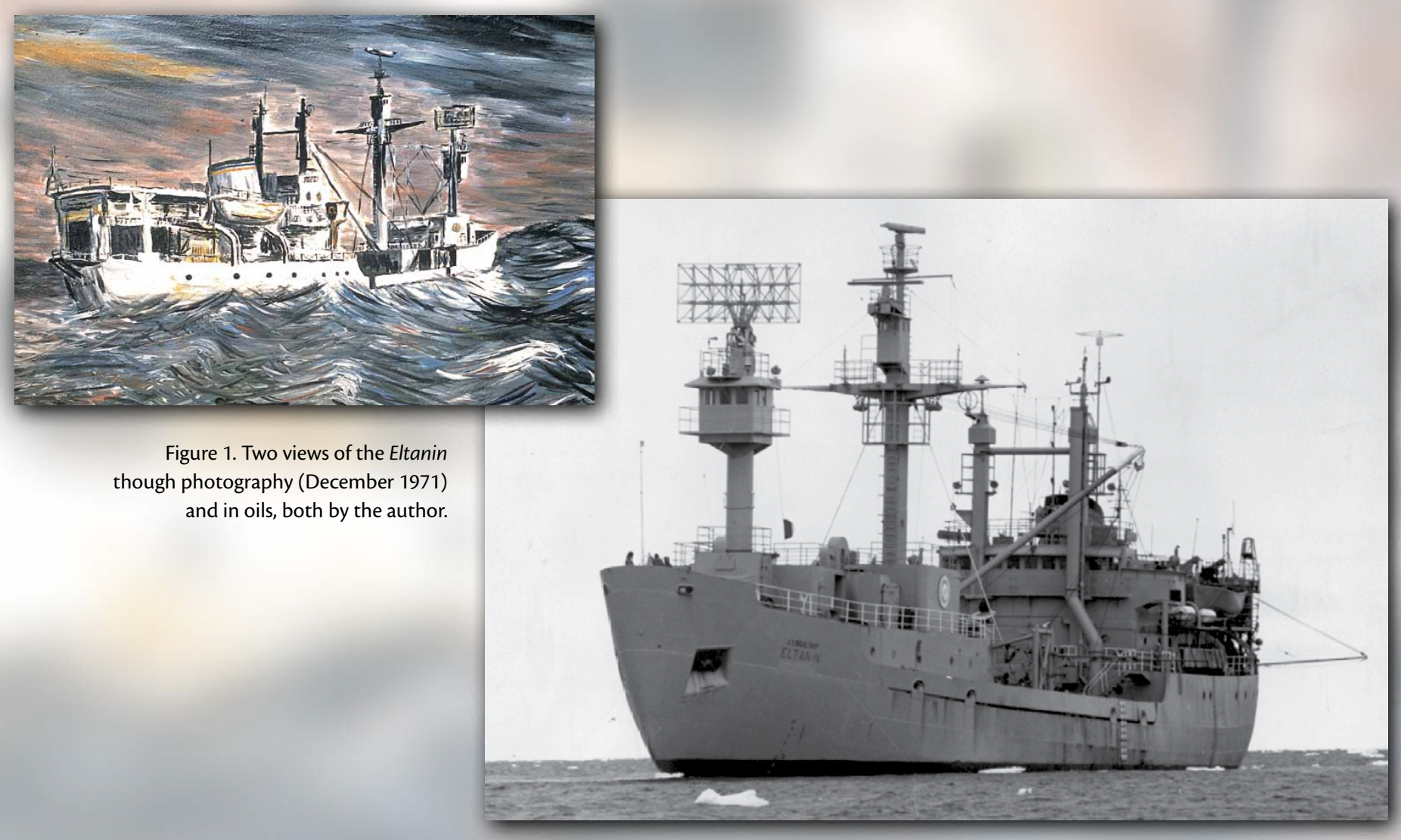


ABSTRACT. The 1962-1992 period spanning the research vessel Eltanin/

Islas Orcadas expeditions to Ice Station Weddell, and the following World Ocean Circulation Experiment, may be viewed as the closing phase of an era of broad-based, circumpolar surveys of the Southern Ocean. Today's investigations of the spatial and temporal dimensions of this complex ocean and its coupling to the climate system integrate observations from ships, aircraft, satellites, tethered instrumentation, and autonomous vehicles with numerical models. However, the adventure of obtaining Southern Ocean observations remains the same, requiring not just the right people and technology, but also special ships capable of working within the harsh Antarctic environment, where unknowns await discovery.

Scientific discovery at sea is exhilarating, an adventure that few experience. For the ocean scientist, the long voyage far away from home is rewarded with new views of how the ocean is stratified and circulates, and with insight on the processes that govern its behavior. Collecting data at sea is especially challenging in remote regions such as the Southern Ocean where harsh wind and wave conditions combined with ice conspire to make observations particularly difficult. Fieldwork in such a hostile environment requires strong ships to provide scientists with safe at-sea working conditions and that can to endure long periods at sea, as the Southern Ocean is far from ports.

As if the environmental conditions were not harsh enough, to make matters dynamically more challenging to oceanographers, the Rossby radius drops from $\sim 100 \mathrm{~km}$ to $\sim 10 \mathrm{~km}$ on moving southward from the Antarctic Circumpolar Current (ACC) to the continental margins. This drop means that ship-based observations must have higher spatial resolution at higher latitudes to resolve the geostrophic scale, which is sometimes tough to do when ice stands in the way.

\section{Besides "adventure," what makes} Southern Ocean fieldwork so enticing is the region's central effects on the global system. It is a role it took on some 30 million years ago upon the establishment of a deep, circum-Antarctic oceanic belt as Drake Passage widened. This geological event has been linked to the thermal isolation of Antarctica and to the chilling of the global climate (Scher and Martin, 2006). Without this deep interoceanic link, global climate would be sharply different from what we have today. The Southern Ocean not only promotes exchange between ocean basins, but it is also the site of major deep-ocean overturning, driven by the sinking of dense upper waters formed at certain sectors along the continental margins. Upon reaching great depths and moving northward, this dense water of Antarctic origin cools and ventilates the abyssal layer of the world ocean, affecting oceanic $\mathrm{CO}_{2}$ storage.

This article focuses on the large-scale surveys required to define the basic structure of the Southern Ocean, from the start of the Eltanin (Figure 1) program in 1962 to the four remarkable months of Ice Station Weddell in 1992 and the World Ocean Circulation Experiment (WOCE) during the early 1990s. These expeditions may be viewed as the closing of an era that began in the nineteenth century and that extended the International Geophysical Year (IGY) of 1957-1958 (Kort, 1969). From 1962 to 1992 , some time-series observations were also acquired from moorings deployed at various sites around Antarctica. For example, the array in Drake Passage during the International Southern Ocean Studies program of the 1970s (Neal and Nowlin, 1979) first resolved the structure and variability of the Antarctic Circumpolar Current (ACC). But the emphasis on capturing the temporal dimension of Southern Ocean variability has become more central only in the last two decades, with increased attention to the development of a coordinated, sustained observational network within the Southern Ocean (Rintoul et al., 2009, 2011).

Georg Wüst (1964) reviews the great expeditions of the nineteenth century up to the 1957-1958 IGY, when oceanographic progress depended directly on observations from these expeditions and their interpretation, usually published in lengthy, detailed monographs. Wüst adds that advances also hinged on technology, improvement of instrumentation,

Arnold L. Gordon (agordon@ldeo. columbia.edu) is Associate Director, Ocean and Climate Physics, Lamont-Doherty Earth Observatory of Columbia University, Palisades, NY, USA. 
and data analysis closely linked to the development of new theoretical concepts (dynamical oceanography). He points out that in oceanographic history, ship names have often been better remembered than those of expedition leaders. In this sense, the Eltanin circumpolar survey is well remembered.

The few data points available in the Southern Ocean before the modern era led scientists to conveniently assume the ocean was in steady state. For them, it was an assumption of necessity (and perhaps a way not to excuse every deviant data point as a sign of change). But oceanographers of the early to midtwentieth century began to appreciate the ocean's temporal variability and to admit that it was not "steady" at all.

\section{ELTANIN AND ISLAS ORCADAS}

It was in the Southern Ocean, with the Eltanin, that I began my oceanographic career in the early 1960s. It was still the time of the great ocean-scale surveys that defined the ocean's spatial characteristics. The Eltanin (Figure 1), supported by the National Science Foundation's Office of Polar Programs, was launched in 1957 as a noncommissioned Navy cargo ship with a special feature that would prove essential to Southern Ocean scientists-an ice-capable, double hull. Thus, this vessel was officially classified as an Icebreaking Cargo Ship. In August of 1962, the ship was refitted to perform research in the Southern Ocean and reclassified an Oceanographic Research Vessel (T-AGOR-8).

Eltanin's research mission included physical, biological, and geologicalgeophysical oceanography. Researchers obtained vertical profiles of temperature, salinity, dissolved oxygen, and other parameters from more than 1,500 "hydro stations" (Figure 2a), along with many thousands of bathythermograph casts and photographs of the seafloor. In the period between 1962 and 1975, the Eltanin logged data along 420,000 nautical miles of track, extending from the Scotia and Weddell Seas westward into the central Indian Ocean, and between $40^{\circ} \mathrm{S}$ and Antarctica. Transferred to the Argentine Navy in 1975 and renamed Islas Orcadas, the ship continued to cruise the Atlantic sector of the Southern Ocean until 1978. The survey of the Southwest Indian Ocean sector was filled in by R/V Conrad cruise 17 of 1974 (Figure 2a; Jacobs and Georgi, 1976), and the perennially ice-covered western Weddell Sea was surveyed in 1992 with the US-Russian Ice Station Weddell (Figure 2b; Gordon and Ice Station Weddell Group of Principal Investigators and Chief Scientists, 1993).

An advantage of participating in a broad survey as a young scientist was that it effectively introduced me to the Southern Ocean, slowly, data bit by data bit, from which emerged broad views of the Antarctic margins and of the ACC, with its assemblage of jets and fronts. ACC characteristics and frontal zonation are not the same at all longitudes, and they respond to bottom topography. For example, the ACC is a broad current with rather ill-defined fronts in the abyssal plain of the Southeast Pacific sector, but it is narrow with sharply defined fronts over the zonal mid-ocean ridge south of Australia and in areas where the current encounters other major topographic features.

I remember attempting to obtain very deepwater samples in the Central
Pacific sector, at a location very remote from ports. I combined two casts to draw a total of 24 water samples from Nansen bottles with reversing thermometers (for more on Nansen bottles, see Warren, 2008). At the sampling location, the ACC squeezes in a jetlike stream through the deep Eltanin Fracture Zone System $\left(50^{\circ} \mathrm{S}, 146^{\circ} \mathrm{W}\right)$. Gauging the Eltanin's rapid eastward drift, we lowered the Nansen cast into the sea upstream of the fracture zone so that hours later it would be dipping exactly into the fracture zone's depths-a great coordinated effort to get a few data points. The ACC then broadens over the Southeast Pacific Basin before reorganizing to pass into Drake Passage and then turning northward in the Scotia Sea to cross the South Atlantic. Although some sectors of the ACC and its frontal zones have been studied in detail since the Eltanin days, particularly at the "choke points" between Antarctica and the warmer Southern Hemisphere continents, there are many other sectors that deserve a closer look. These would include a revisit to that most dramatic choke point at the Eltanin Fracture Zone System and other encounters of the ACC with specific topographic features, such as the various plateaus of the Indian Ocean.

There are two processes by which Southern Ocean surface waters may reach the deep ocean: gravity currents over the continental slope and convection in the open ocean similar to what occurs within the Greenland and Labrador Seas (Gordon, 1991). In February 1977, the Islas Orcadas found clear evidence of the latter process when scientists aboard the ship observed the remnants of a convective "chimney" near Maud Rise in the Weddell Sea. This 
observation was key in linking deepocean convective processes to the "Great Weddell Polynya," a 250 x 103 km² area virtually free of sea ice during the winters of 1974-1976, in the midst of a region that is normally covered with seasonal sea ice (Gordon, 1978).

The Weddell Polynya was observed shortly after satellites began to gather images of the Southern Ocean sea ice fields, but a persistent, winter-long polynya hasn't formed again since 1976 within the Weddell Gyre. Archived observations of surface-layer salinity within that larger area suggest that the Great Weddell Polynya of 1974-1976 may have been induced by a prolonged period of negative or neutral Southern Annular Mode (SAM) index, which also occurred in the leading decade of the twentieth century (Gordon et al., 2007). Might the Weddell Polynya have occurred in that earlier period? Did the 1911-1912 Deutschland expedition into the Weddell Sea region (Brennecke, 1921) record deep-reaching convection, as Wüst (1928) interpreted the Deutschland data? A series of papers by Wüst (1933, 1935) and Mosby (1934) turned the tide of opinion to the continental margin origin of Antarctic Bottom Water (AABW). Perhaps the nonsteady state issue needed to be considered then?

\section{ICE STATION WEDDELL}

The Islas Orcadas work led to two decades of expeditions in the central Weddell Gyre. In the 1980s, a series of winter and spring expeditions (Somov, 1981; PoIarstern, 1986, 1989; Fedorov 1989; see Gordon and Huber, 1990) provided a more precise view of the deepwater coupling with the winter mixed layer and its control of seasonal sea ice distribution and thickness. Over the far western limb of the Weddell Gyre, however, high concentration of perennial sea ice had hindered even the basic exploration of the northward-flowing western boundary current carrying the densest forms of AABW. This region is
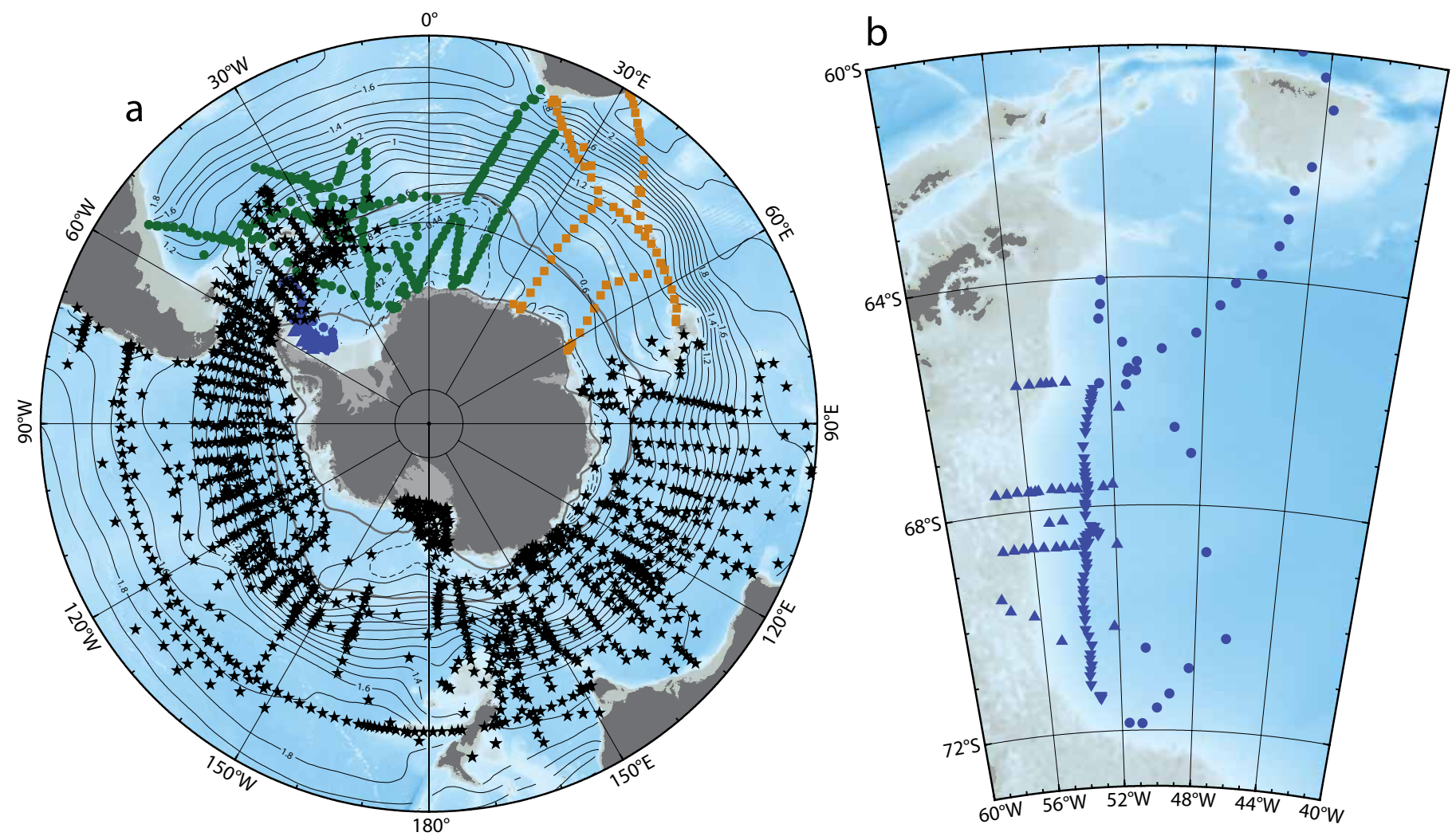

Figure 2. (a) Circumpolar Survey 1962-1992: Eltanin (black stars), Islas Orcadas (green circles), Conrad 17 (orange boxes), Ice Station Weddell stations (blue symbols). Bathymetry is from Smith and Sandwell (1997). Maximum and minimum ice edge (February and September; gray lines), 1979-2007 average, from the National Snow and Ice Data center. The black lines denote the 0/1500 dynamic height from the World Ocean Atlas 2009 (http://www.nodc.noaa.gov/OC5/WOA09/pr_woa09.html). (b) Expanded map showing Ice Station Weddell conductivity-temperature-depth (CTD) stations. Inverted triangles mark the sites of the CTDs obtained from the drifting ice floe, upright triangles indicate CTDs obtained from helicopter flights off the ice floe, and solid circles denote ship-based CTD casts. 
precisely where, on January 18, 1915, the Endurance and Sir Ernest Shackleton and his crew were stranded in the Weddell Sea ice pack and began the most famous example of survival in polar exploration (Shackleton, 1919).

An effective and successful method for gathering extensive observations in the ice-cluttered western Weddell Sea was borrowed from the Arctic: deployment of a scientific station on a drifting ice floe. On February 12, 1992, Ice Station Weddell (ISW) was established at $71.4^{\circ} \mathrm{S}$ by a joint effort of the United States and Russia (Gordon and Ice Station Weddell Group of Principal Investigators and Chief Scientists, 1993)
(Gordon and Ice Station Weddell Group of Principal Investigators and Chief Scientists, 1993). Observations were also made from remote instrumented drifters, helicopters, and ships associated with the various phases of the ISW fieldwork (Figure 2b). The US and Russian science programs complemented each other to yield a more complete picture of the environment. Measurements included thermohaline and tracer fields, currents, and turbulent fluxes within oceanic and atmospheric planetary boundary layers. These data were used in studies of sea ice dynamics, sea ice physical, chemical, and biological characteristics, and water column biology.

...THE ADVENTURE OF OBTAINING

SOUTHERN OCEAN OBSERVATIONS REMAINS

THE SAME, REQUIRING NOT JUST THE RIGHT

PEOPLE AND TECHNOLOGY, BUT ALSO SPECIAL

SHIPS CAPABLE OF WORKING WITHIN THE

HARSH ANTARCTIC ENVIRONMENT, WHERE

UNKNOWNS AWAIT DISCOVERY.

during which participating researchers drifted until June 4 with the perennial ice, roughly from $53^{\circ} \mathrm{W}$ to $65.8^{\circ} \mathrm{S}$ along the western boundary of the Weddell Gyre (Figure 2b).

During ISW, the floe drifted at a mean speed of $6.6 \mathrm{~km}$ per day. Scientists collected an impressive array of data at the camp along a $750 \mathrm{~km}$ path that closely followed the track of the Endurance

\section{CONCLUDING REMARKS}

From 1989 to the mid-1990s, a series of oceanographic sections were obtained in the Southern Ocean as part of WOCE (see the WOCE Southern Ocean Atlas by Orsi and Whitworth, 2005; http:// woceatlas.tamu.edu). Gradually, the broad spatial survey effort yielded to emphasis on temporal scales and mesoscale to submesoscale process studies. We now have repeats of the WOCE sections within the CLIVAR (Climate Variability and Predictability) program, as well as sustained measurements from mooring arrays, Lagrangian drifters, and profiling floats. The Argo array provides circumpolar snapshot views, enabling study of shifting fronts in association with a changing SAM index, although not yet of the Rossby radius series of observations across the circumpolar zones as brought out by the survey sections. The surveys of the past have enabled a view of the slow temporal changes that the climate system is presently undergoing (Purkey and Johnson, 2010).

In today's world, as measurements from multiple instruments and platforms work together with a suite of numerical models to leverage the still-limited observations into a broader picture, the right combination of capable scientists and ships are needed to sustain Southern Ocean adventure and discovery.

\section{ACKNOWLEDGEMENTS}

My years of Southern Ocean research were funded by the National Science Foundation, Office of Polar Programs. I appreciate the support of a string of chief scientists and program managers, among them Albert Crary, Louis Quam, John Kelley, Victor Neal, Peter Wilkniss, Bernard Lettau, and most recently Peter Milne. LamontDoherty Earth Observatory contribution number 7562. 四 


\section{REFERENCES}

Brennecke, W. 1921. Die ozeanographischen arbeiten der Deutschen Antarktischen Expedition, 1911-1912. Archiv der Deutschen Seewarte 39:1-125.

Gordon, A.L. 1978. Deep Antarctic convection west of Maud Rise. Journal of Physical Oceanography 8(4):600-612, http:// dx.doi.org/10.1175/1520-0485(1978)008 $<0600$ :DACWOM>2.0.CO;2.

Gordon, A.L. 1991. Two stable modes of Southern Ocean winter stratification. Pp. 17-35 in Deep Convection and Water Mass Formation in the Ocean. J. Gascard and P. Chu, eds, Elsevier.

Gordon, A.L., and B. Huber. 1990. Southern Ocean winter mixed layer. Journal of Geophysical Research 95(C7):11,655-11,672, http:// dx.doi.org/10.1029/JC095iC07p11655.

Gordon, A.L., and Ice Station Weddell Group of Principal Investigators and Chief Scientists. 1993. Weddell Sea exploration from ice station. Eos, Transactions American Geophysical Union 74(11), 121, http://dx.doi.org/ 10.1029/93EO00260.

Gordon, A.L., M. Visbeck, and J.C. Comiso. 2007. A possible link between the Weddell Polynya and the Southern Annular Mode. Journal of Climate 20(11):2,558-2,571, http://dx.doi.org/ 10.1175/JCLI4046.1.

Jacobs, S.S., and D.T. Georgi. 1977. Observations on the Southwest Indian/Antarctic Ocean. Pp. 43-84 in A Voyage of Discovery. M. Angel, ed., Supplement to Deep Sea Research, vol. 24.

Kort, V.G. 1969. Oceanographic investigations in the Antarctic. Chapter 3.4 in Annual of the International Geophysical Year, vol. XLVI. A.L. Gordon and F.W.G. Baker, eds, Pergamon Press.

Mosby, H. 1934. The waters of the Atlantic Antarctic Ocean. Pp. 1-131 in Scientific Results Norwegian Antarctic Expedition, 1927-1928, vol. 11.

Neal, V.T., and W.D. Nowlin. 1979. International southern ocean studies of circumpolar dynamics. Polar Record 19:461-471, http://dx.doi.org/ $10.1017 /$ S0032247400002400.

Orsi, A.H., and T. Whitworth III. Hydrographic Atlas of the World Ocean Circulation Experiment (WOCE) Volume 1: Southern Ocean. Series edited by M. Sparrow, P. Chapman, and J. Gould, http://woceatlas.tamu.edu/Sites/html/ atlas/SOA_PRINTED.html.

Purkey, S.G., and G.C. Johnson. 2010. Warming of global abyssal and deep Southern Ocean waters between the 1990s and 2000s: Contributions to global heat and sea level rise budgets. Journal of Climate 23:6,336-6,351, http://dx.doi.org/ 10.1175/2010JCLI3682.1.

Rintoul, S.R., M. Balmeseda, S. Cunningham, B.D. Dushaw, S. Garzoli, A.L. Gordon, P. Heimbach, M. Hood, G.C. Johnson, M. Latif, and others. 2010. Deep circulation and meridional overturning: Recent progress and a strategy for sustained observations. In Proceedings of OceanObs'09: Sustained Ocean Observations and Information for Society, vol. 1. Venice, Italy, September 21-25, 2009, J. Hall, D.E. Harrison, and D. Stammer, eds, ESA Publication WPP-306, http://dx.doi.org/ 10.5270/OceanObs09.pp.32.

Rintoul, S.R., M. Sparrow, M. Meredith, V. Wadley, K. Speer, E. Hofmann, C. Summerhayes, E. Urban, and R. Bellerby. 2012. The Southern Ocean Observing System: Initial Science and Implementation Strategy. SCAR, Cambridge. 74 pp.

Scher, H.D., and E.E. Martin. 2006. Timing and climatic consequences of the opening of Drake Passage. Science 312:428-430, http://dx.doi.org/ 10.1126/science.1120044.

Shackleton, E. 1919. South. William Heinemann, London, 368 pp. [see also Shackleton, E. 1982. South: The Story of Shackleton's Last Expedition 1914-1917. Century Publishing, London.]

Smith, W.H.F., and D.T. Sandwell, 1997. Global sea floor topography from satellite altimetry and ship depth soundings. Science 277:1,957-1,962, http://dx.doi.org/ 10.1126/science.277.5334.1956.

Warren, B.A. 2008. Nansen-bottle stations at the Woods Hole Oceanographic Institution. Deep Sea Research Part I 55(4):379-395, http:// dx.doi.org/10.1016/j.dsr.2007.10.003.

Wüst, G. 1928. Der Ursprung der Atlantischen Tiefenwassar. Jubiläums-Sonderband. Z. d. Ges. F. Erdkunde, Berlin.

Wüst, G. 1933. Das Bodenwassar und die Gliederung der Atlantischen Tiefsee. Wissenschaftliche Ergebnisse der Deutschen Atlantischen Expedition Meteor, 1925-1927 6(1):1-106.

Wüst, G., 1935. Schichtung und Zirkulation des Atlantischen Ozeans: Die Stratophaere. In: Wissenschaftliche Ergebnisse der Deutschen Atlantischen Expedition auf dem Forschungsund Vermessungsschiff "Meteor" 1925-1927, vol. 6, first part, 2, Berlin, 180 pp. (English translation: Emery, W.J., ed. 1978. The Stratosphere of the Atlantic Ocean. Amerind, New Delhi, 112 pp.)

Wüst, G. 1964. The major deep-sea expeditions and research vessels 1873-1960: A contribution to the history of oceanography. Progress In Oceanography 2:1-52, http://dx.doi.org/ 10.1016/0079-6611(64)90002-3. 